\title{
Class Formation in Sweden and Britain: Educating Workers
}

\author{
Jenny Jansson ${ }^{1}$ \\ Uppsala University
}

\begin{abstract}
The European labor movements developed in different directions during the twentieth century. The class formation literature has tried to explain these differences but left unexplored the internal dynamics of the labor movement and, above all, the differences in ideological schooling. Workers' education constitutes a forum for ideological schooling of members, and these educational settings can be identity constitutive and thus play an important part in the class formation process. In this article I analyze the institutions for workers' education in Sweden and Britain and I suggest that the variation of the design and practices of workers' education had an impact on the movements' developments in terms of identity formation and cohesiveness.
\end{abstract}

The labor movement came to play a crucial role in the development of welfare states and democracy in the early twentieth century. Democratic citizenship was promoted by the reformist labor movement and became an important part of the consolidation of democracy during the interwar period. There were, however, significant differences between the European labor movements in terms of size, cohesiveness, ideology, and, ultimately, influence. In some of the Nordic countries, especially Sweden, the reformist labor movement became strong, unified, and influential. These countries developed comprehensive welfare states and peaceful industrial relations, while in other countries the labor movement was more fragmented. Different ideological factions ended up in conflict with each other instead of struggling together, making labor weak. Meanwhile in Spain, Italy, and Germany fascist movements overthrew democracy with support from parts of the working class. ${ }^{2}$

How can we understand these national differences? There are varied explanations for the relative strength and ideology of the labor movements in Europe. The most common ones focus on structural variables and take the class formation literature as their point of departure. The internal dynamics of the labor movement and especially the differences in ideological schooling have, with few exceptions, not been the focus of comparative research on national labor movements. In this article I argue that examining workers' education may offer a path to a deeper understanding of the class formation process and, thus, a clearer grasp of national differences among labor movements. Workers' education constitutes a forum for ideological schooling of members that can be and has been identity-constitutive.

To understand how class formation took place in different countries, we need to include workers' education in the analysis. In this article I analyze 
workers' education in two empirically interesting countries: Britain and Sweden. I argue that the design and practices of workers' education had an impact on the movements' developments in terms of identity formation and cohesiveness. I first develop the theoretical argument of why workers' education should be considered an important part of class formation. In the second part, I summarize the differences between the Swedish and the British labor and worker education movements, which developed very differently from each other during the twentieth century. The third part compares and analyzes the two cases, and in the fourth part I present some conclusions.

\section{Workers' Education: An Essential Part of Class Formation?}

Prior research on identity formation in the labor movement has taken as its point of departure the literature on class formation - namely, the process by which the working class develops a common understanding of its position in society and begins to act as a collective. This literature can be divided roughly into two streams or schools of thought: one concerned primarily with "lived experience" and another on language and discursive transformations. Contributions to the first school emphasize the role of industry structure and conditions in determining the character of workers' experience as a class and, therefore, the formation of their class consciousness and the nature of the labor movement. ${ }^{3}$ The most influential representatives of this school are E.P. Thompson and Ira Katznelson. ${ }^{4}$ A postmodernist reaction to the "lived experience" school emerged in the 1980s. The objections to the "old" approach did not dispute the core issues of the class formation process: The critics still viewed lived experience as crucial for the emergence of a working-class consciousness. But they did criticize the methods of the older school. In order for class culture to exist and for lived experiences to contribute to its formation, there had to be a language in which the culture and the experiences were expressed. Discourse, according to this research field, facilitates and constrains actions. To capture fully these effects on class formation, language needed to be at the center of the analysis. ${ }^{5}$

However, in neither of these approaches were the actors given much power over the formulation and articulation of their experience or the language within which it was expressed. This neglect reveals a gap in both the theoretical treatment of and the empirical research on class formation. Because identity is assumed to emerge as a result of structures, whether industrial or linguistic, the actors' role, especially the role of leaders in identity formation processes has been overlooked. In methodological terms, the focus on structures has led researchers to concentrate on objective conditions or discourse as the independent variable explaining class formation and has left the actors relatively unexplored. Of course, structures play a role in class formation. But research on social identities has argued that structural factors are not sufficient for developing identities. Instead, researchers find that social structures create prerequisites for social identities and that the actual emergence of a specific social identity depends upon whether it is "activated." ${ }^{6}$ Leaders typically activate identities 
in organizations, where they play the role of "identity entrepreneurs." want to fully understand class formation, understanding the influential role of leaders in formulating a cohesive organizational identity is an important piece of the puzzle. Moreover, I would argue that leaders who understand that workers' education can be an instrument for shaping class identity can have a significant impact on class formation.

\section{Workers' Education: An Instrument in Class Formation}

Workers' education became an integral part of the labor movement's activities around the turn of the nineteenth century. In general, two different aims crystallized for workers' education programs. On the one hand, education was supposed to compensate workers for their comparatively low level of education and thus to raise the workers' knowledge and skills in different subjects. On the other hand, some advocates of workers' education emphasized the importance of "enlightening" the working class, since without insights and cultural knowledge they would never be able to seize power. ${ }^{8}$ These theorists and practitioners did not stress the appropriation of specific skills so much as the ability to analyze and appreciate the arts and sciences, as well as politics and society. The working class should be enlightened, liberated from the oppressive burden of its ignorance and thus transformed from "individuals into human beings." 9

Many socialist theorists, including Karl Marx, Eduard Bernstein, Antonio Gramsci, and Vladimir Lenin, stressed education as a key component for the realization of socialism. Bourgeois schools would reproduce bourgeois values. To control which knowledge was considered necessary and important for the working class was to acknowledge and to realize discursive power. The privilege to decide what counted as knowledge, what was culture, and what social problems were important, was an essential part of transforming a bourgeois society into a socialist one.

But discursive power also applied to the labor leaders. By privileging some themes of workers' education over others, leaders could influence what was taught and thereby produce and reproduce certain ideological ideas. The education system, moreover, constituted an excellent means for disseminating ideas to the rank and file. It was a valuable mechanism for leaders who wished to impact identity formation in the movement. I argue below that education programs were identity-constitutive for two reasons.

First, workers' education offered a perfect opportunity for the leaders to communicate their definitions and views of social problems, class struggle, and the aims of the labor movement to members. Study activities aimed at educating and enlightening the rank and file provided a forum where labor leaders, because they could control and design the study activities, could reach a wide range of the membership. The means to communicate with the members were fewer in the 1920s than they are today: Workers' education was one of the few channels for direct communication. Whoever controlled what was taught 
in the education programs could have an impact on the ideology of the movement. By controlling the content of the education, leaders could manage the image of the organization transmitted to the members. In particular, courses like "trade union studies" or "history of the labor movement" were an opportunity to plant ideas about "who we are" among members at the grassroots level, since they were focused on what the labor movement was and did. A cohesive image of the aim and ideology of the movement also functioned as a glue or binding agent among workers around the country. By transmitting the same image of what it meant to be a worker through education programs across the country, the working class could be encouraged to think along the same lines, which is a precondition for cohesiveness in the labor movement. Content could thus breed solidarity and controlling the content of education affected the kind of working class consciousness that developed. Moreover, since workers' education challenges members to contemplate such issues as class, the labor movement, and the workers' position in society, identity formation in these settings was clearly connected to class identity.

Second, education programs encourage identity formation as much by their form as by their content. Membership in the labor movement is voluntary and members thus have influence over the development of the movement. Leaders can not deviate too much from the opinions of the grass roots. Doing so risks splitting the movement or encouraging defections. But leaders can more safely influence the rank and file through "soft steering." Properly designed, education programs are one example of such soft steering methods. Small educational settings focusing on discussions and deliberation are more likely to promote the development of a sense of "we". Research on the impact of study circle activities' on participants suggests that the form of the study activity itself raises self-confidence among the members, helps participants to define their position in the society, and improves debating skills. ${ }^{10}$ Small assemblies of workers from the local community attending different forms of workers' education by themselves create a sense of belonging. In such educational settings the participants often worked together or belonged to the same union section or political organization. The identification process from the study activities transfers into solidarity in other arenas. Compared to lectures where the participants only sat and listened, nonhierarchical, interactive study activities, like the study circle, had a more profound impact on identity formation.

The analysis that follows takes its point of departure in these arguments. Working-class formation in Britain and Sweden is considered from the standpoint of the different systems of worker education found in each country. The argument as a whole is premised on the claim that the labor movements in these two countries differ in significant ways and that therefore so did the approach to education taken in each - and vice versa: The different forms of education affected the process of class formation. The analysis is carried out in two steps. First, the labor movements in the two countries are compared and contrasted. Then their workers' education systems are compared, including their relationship to the trade union movement and working-class parties. The goal of 
the analysis is to answer the question, how was workers' education organized and who controlled, to what effect? Moreover, and as will be shown, workers' education plays an important role in the class formation process not only through leaders' control of the education, but also because of the forms of the education activities. Therefore, the second step of the analysis also compares the forms workers' education took in Britain and Sweden.

\section{Comparing the Swedish and British Labor Movements}

The post-World War Two Swedish labor movement has often been described as among the strongest in the world. But this was not the case before the war. After a failed general strike in 1909, the affiliates of the Trade Union Confederation (LO) argued that the confederation had too much power, which had led to the great defeat, and they insisted that the movement become more decentralized. ${ }^{11}$ Strengthening the affiliates' powers vis-à-vis the national office, however, adversely affected labor market relations, which continued to be marred by frequent conflicts. Sweden actually experienced the most labor market conflicts in the world in the 1920 s. $^{12}$ The situation then changed drastically after the Employers' Organization (SAF) and the LO concluded the Basic Agreement of 1938 (Saltsjöbadsavtalen), an historic labor market agreement that effectively ended strikes and lockouts and set the stage for the labor-management cooperation that has until recently been the dominant feature of the so-called "Swedish model." As a result of this agreement, union density in Sweden during the postwar period grew to an estimated sixty-five to eighty percent. ${ }^{13}$ Also, the trade union movement now had the power to improve working conditions, reduce the wage gap, and promote the construction of a comprehensive Swedish welfare state. A strong, cohesive labor movement also led directly to the dominance of the Social Democratic Party, which would hold power at one point for forty-four years in a row. ${ }^{14}$

In contrast, the British labor movement is commonly understood to have been one of the strongest and most successful labor movements in the world at the beginning of the twentieth century. Only Germany could compete with it in terms of size and influence. The British working class was large, and the structure of British industry favored working-class mobilization. In fact, from the perspective of prevalent class formation theories, Britain is a sound case for observing the development of working-class consciousness. Both the Swedish and the British labor movements can be characterized as pragmatic movements in which socialist theorists played a minor role in the daily work of the unions. ${ }^{15}$ In Britain, neither the union movement nor the party split into right- and left-wing fractions the way they did, for instance, in Germany or France, where different factions fought each other. However, just like the Swedish labor movement, the British reformist union movement experienced challenges from left-wing groups, particularly from communists. ${ }^{16}$

Despite these similarities, the Swedish and British movements developed in very different directions during the post-World War Two period. The British 
union movement proved less successful than Sweden's LO in terms of size, coherence, and influence. Among other things, the British movement was never as centralized as the Swedish movement was before 1910 or again in the 1930s. The affiliates of the British Trade Union Congress (TUC) had considerable powers over the movement at the expense of its cohesion. ${ }^{17}$ More importantly, the British union movement became more radical than the Swedish in the sense that its relationship with employers was more confrontational. The number of labor market conflicts after 1945 was consequently much higher in the UK than in Sweden. ${ }^{18}$ Also, union density in Great Britain after World War Two was stable at around forty percent, which was significantly lower than in Sweden. And while the Labour Party did hold office at various times after 1945, it never dominated British politics the way the Social Democrats did in Sweden. ${ }^{19}$ In short, the labor movements in Sweden and Britain were significantly different in terms of outcomes after World War Two.

The interwar period thus constitutes an interesting interval for examining class formation. Identity formation processes in organizations are usually triggered by some kind of incident that forces the management of the organization to question current perceptions. These changed circumstances can either be altered by external threats, which trigger the idea of changing the identity, or problems can originate from inside the organization. ${ }^{20}$ Hence, in order to study active identity formation, we should choose a time period when the organizations were challenged. In our case, the emergence of rival left-wing organizations will serve as such a case. If labor leaders ever tried to manage identity formation, this is a time when we would expect them to have acted. Therefore, the 1910-1930 period is suitable for comparative study, since leftwing movements existed in both countries, mounted significant challenges to the dominant, more reformist central federations of labor in both, and grew in strength at about the same time. ${ }^{21}$ Comparing workers' education in these two countries can thus help us understand what role (if any) workers' education played in class formation. Given the difference in outcomes, if workers' education was organized the same way in both countries, we can reject the hypothesis that workers' education had an impact on working-class formation.

\section{Workers' Education in Britain: Divided and Radical}

Throughout the nineteenth century, workers' education system grew in importance in Britain, quickly developing in several directions and resulting in different organizations: workers' colleges, the university extension movement, the Workers' Educational Association (WEA), the Fabian Society, and labor organizations' own schools, such as Trades Union Congress' (TUC) summer school for activists. ${ }^{22}$ Among the variety of educational institutions that emerged during the first decades of the twentieth century, the most prominent ones were the WEA, National Council for Labour Colleges (NCLC), Plebs League (later absorbed by the NCLC), and syllabus contributions by the Labour Research Department (LRD). 
The Workers' Educational Association (WEA) was founded by Dr. Albert Mansbridge in 1903 and was the first national workers' educational organization in the world. ${ }^{23}$ During its first years the WEA collaborated with the British higher education system to offer programs in workers' education and also affiliated with Ruskin College, a residential workers' college in Oxford (but not officially part of the university there). ${ }^{24}$ The WEA had only existed for a few years when an opposition emerged, the so-called independent working class education movement, led by radical left-wing activists, who were opposed to the WEA's approach to workers' education. In 1908, dissatisfied with what they felt was not enough Marxists on the faculty, students at Ruskin College staged a strike. ${ }^{25}$ The strike had two principal results. First, an independent Central Labour College (CLC) was founded, which became the mainstay of the independent workers' education movement. ${ }^{26}$ Second, a group of Ruskin students founded the Plebs' League, a political organization with Marxist ideals, and began to publish The Plebs, a radical workers' education magazine. The Plebs' League worked closely with the several labor colleges that had been established around the country and attracted many left-wing activists in the labor movement-not only to the bourgeoisie, but also to the WEA. ${ }^{27}$

The success of the labor colleges led to the founding of a second major national organization for education, the National Council of Labour Colleges (NCLC), which was established in 1921. This NCLC aimed to coordinate the labor colleges in Britain. Naturally, it had a close relationship with the Plebs' League, which it eventually absorbed. The combined organization became the main voice of the independent workers' education movement. ${ }^{28}$ Unlike the WEA, the NCLC advocated "independence" for workers' education. The working-class movement, it insisted, needed education that was not infused with upper-class values. Labor colleges, the NCLC argued, were run by the labor movement, while WEA classes were provided through the university extension movement and thus arranged by upper-class institutions. ${ }^{29}$ Beware of "capitalist-provided education," Arthur Woodburn, the president of the NCLC, warned, since it was not impartial. ${ }^{30}$

Conflict between the WEA and NCLC over impartiality and independence characterized the 1920s and 1930s. Since both organizations claimed to have the correct approach to organizing workers' education and were dependent on funding from affiliated unions, the competition between them led to a split in the workers' education movement. Public grants to the study activities turned out to be an especially contested issue. The NCLC accused the WEA of organizing "bourgeois education" not only because of its cooperation with universities, but also because the WEA received public funding. The conflicting views on ideology and workers' education between the NCLC and WEA is well expressed in the NCLC annual report from 1925:

The progress of the Labour College Movement had seriously alarmed both Ruskin College and the WEA who, despite the fact that they receive large subsidies for their educational work from capitalist state funds while the Labour 
Colleges do not receive a penny, were feeling the ground slipping from beneath their feet. $^{31}$

The WEA dismissed the critique and instead criticized the NCLC for being a Marxist party school. ${ }^{32}$

If the teacher is a specialist in political philosophy and he cannot teach political philosophy without dragging his subject through the party political cockpit, he is not a teacher at all. He is merely a tub-thumping charlatan. ${ }^{33}$

The NCLC was not the only organization concerned about the grants to the WEA. The Workers' Educational Trade Union Committee (WETUC) was founded in 1919 by the TUC in an attempt to intensify its engagement in workers' education and to exercise more influence over the WEA's activities. ${ }^{34}$ The latter had grown quickly and by 1920 had a membership of approximately 2,700 trade union sections and other voluntary organizations, as well as 20,000 individual members. The WEA was thus a large organization over which the TUC had little influence. The WETUC formally affiliated to the WEA and used its teaching materials, but the TUC rather than the WEA controlled the work of the committee. ${ }^{35}$

Besides the WEA and the independent workers' education, two more organizations are worth mentioning: the Fabian Society and the Labour Research Department. Both were advocates of workers' education though neither of them were educational institutions per se. The Fabian Society, founded in 1884, was a small organization of intellectuals who championed a reformist brand of socialism. Under the banner of "educate, agitate, organize," the Fabians organized summer schools, weekend schools, courses and lectures on socialism and topics related to social issues. ${ }^{36}$ In 1912 it established the Fabian Research Department, eventually renamed the Labour Research Department (LRD), which produced reports and research for the trade unions. The LRD also published a syllabus for study circles and courses, suggesting topics for workers' education. ${ }^{37}$ The Fabians and LRD never engaged in the conflicts over independent workers' education.

If we move from the several organizations concerned with workers' education in Great Britain to the forms the education being offered actually took, we find several different types of educational practices. The so-called University Extension Movement (UEM) had been established at the end of the nineteenth century in order to make postsecondary education accessible to adults who did not have the means to study at a university. ${ }^{38}$ The UEM was a common pathway for collaboration between the social movements, including labor, and established universities. Consequently, teaching practices in movement organizations became a mixture of methods developed by social movements and those used by the formal education system (such as universities and high schools).

The repertoire of teaching methods used by WEA was diverse: tutorial classes, seminars, in-depth studies of subjects, and more. ${ }^{39}$ The most prominent 
method, the tutorial classes, was a reaction against the hierarchical teaching methods used by universities. These were smaller classes, where the students chose the topics to be studied, and the classes consisted of both lectures and discussions. The latter were the most important element of the tutorial method, however, which revolved around the tutor. ${ }^{40}$ The tutors were to be trained by a university, knowledgeable about the subject they were to teach, and devoted to the aims of the WEA. ${ }^{41}$

Compared to university teaching methods, the tutorial classes were something new and different. But they nevertheless had elements of more hierarchical teaching methods, such as the university-trained tutors, than was characteristic of the study circle tradition in Sweden. Course instructions written by a prominent WEA instructor, for example, directed students to ask the tutor for reading material rather than to rely upon the local public library for suggestions. ${ }^{42}$ Unlike study circles, the tutorial classes also attempted to exercise more control over what students were learning by requiring that participants in a class write essays. Tutorial classes also charged student fees. ${ }^{43}$ Finally, many of the classes were designed and taught by professors and other university employees. Several of the leading instructors in the WEA, in fact, including socialist thinkers like R. H. Tawney, William Temple, and G.D.H. Cole, had college degrees from Oxford and held prestigious positions at the university at various stages of their career. ${ }^{4}$ In comparison to the Swedish system, therefore, workers' education in Britain bore a greater resemblance to university education, despite the fact that it operated separately from it, than was true in Sweden. Swedish popular education, as we shall see, including workers' education, took as its point of departure the very different self-study tradition.

While the independent workers' education movement opposed the WEA's dependence on government funding, it did not reject the methods adopted from WEA. The NCLC offered a variety of education options to workers: evening classes, day classes, correspondence tuition, lectures by post, summer schools, weekend schools, and other arrangements. Subjects were chosen to help students carry on their work in the trade unions more effectively. ${ }^{45}$ Most of the teaching, though, took its point of departure from lectures and teacher-led classes, similar to the WEA.

Even though some part of the British workers' education system stressed enlightenment of the working class, the heritage of the UEM stressed education rather than enlightenment. One reason for this emphasis was the expectation that the new Labour Party would eventually enter the government. The universities had traditionally educated bureaucrats to run the state. With the workingclass vote growing rapidly, workers themselves would eventually take power, and, when that happened, they would need to have an education that prepared them to govern. ${ }^{46}$ This emphasis on training the next generation of officials also encouraged the adoption of hierarchical rather than democratic forms of study.

In summary, workers' education in Britain was split into different bodies with different ideological aims that opposed each other. Unions supported all of them but were in control of none. On the contrary, the educational 
organizations in the labor movement appear to have been independent from both the unions and the Labour Party. Worker education organizations also attracted left-wing radical activists, as well as those without a working-class background. This was especially true regarding the leading elements of the WEA and the Fabians. There is little to indicate that the union movement tried to seize control over the educational sphere. The WETUC was intended to exercise such control, but it was not a well-coordinated attempt supported by a united union movement. Instead, the unions were split between the different fractions. In short, the circumstances of workers' education in Britain did not favor its use by labor leaders as an instrument for class formation.

\section{Workers' Education in Sweden: Uniform and Reformist}

The labor movement was the last of three social movements that mobilized large portions of the Swedish population during the nineteenth century. ${ }^{47}$ The temperance movement and the free churches movement had both preceded it and they had supported a system of popular education, which called for establishing libraries and study circles throughout Sweden. The labor movement then later adopted and used this system for its own purposes. ${ }^{48}$ Indeed, the fact that the phrase "workers' education" was and is not used widely in Sweden reveals the extent to which the labor movement's educational work built upon the earlier legacy of movements like that for temperance.

The Swedish labor movement established the Workers' Educational Association (Arbetarnas bildningsförbund) (ABF) in 1912 after the government decided to allocate state funding to national organizations that administered study circle libraries. Even though the Swedish state funded popular education, however, study circles and peoples' high schools operated autonomously from the government. ${ }^{49}$ Thus, state funding of workers' education did not trigger a debate about independence in Sweden. Unlike the WEA, the ABF did not cooperate with established, formal educational institutions. Instead, the ABF focused on creating its own libraries around the country and facilitated the formation of study circles by providing syllabi and learning materials for them. ${ }^{50}$ The only full-time study activities arranged by the ABF were organized in cooperation with peoples' high schools (folkhögskolor), which had been established in various parts of the country. These programs did not, however, dominate the activities of the ABF.

Initially, there was only one trade union confederation, one party, and one youth organization in Sweden. This situation changed somewhat in the 1910s when a competing syndicalist organization, the SAC (Sveriges arbetares centralorganisation) split off from the LO. Then, a few years later the Social Democratic Party, SAP (Socialdemokratiska arbetarpartiet), and its youth organization split. The increasing number of parties created a complex situation for the $A B F^{51}$ In 1918, the year after the party split, the Left Party and the new Social Democratic Youth League (SSU) were granted membership in the $\mathrm{ABF}^{52}$ In 1919, at the first meeting at which the new organizations were 
represented, the representative of the Left Party's youth organization proposed changes in the leadership of the ABF, accusing its president, Rickard Sandler, a leading Social Democrat and a founder of the ABF, of not doing his job. Building socialism required, the youth organization argued, that the ABF leadership be focused on education, not administration. To encourage this shift, the youth organization proposed that the central offices of the ABF be moved from Brunnsvik in the northerly, more remote region of Dalarna to Stockholm. ${ }^{53}$

Moving the central bureau from Brunnsvik may have had logistical advantages, but that was not the only reason the left-wing youth organization made the suggestion. In 1918 Brunnsvik was already a stronghold of the reformist labor movement, and its remote location made it more difficult for other organizations to gain access to or exercise influence over the central office. The proposal, which was turned down by the ABF's governing body, could thus be interpreted as an attempt to break the SAP's grip on the organization. Nevertheless, after a few left-wing organizations joined the ABF and secured seats on its governing body, they attacked the reformist emphasis of the organization's popular education program. In response, the SAP proposed a change in the structure of the ABF's governing body in 1919 to guarantee better representation for the three largest organizations in the association - the SAP, LO, and Cooperative Union - which provided eighty-five percent of the membership fees in the ABF. At that time the ABF had nine member organizations, with more wanting to join. Under the old voting rules, each member organization had one vote, which gave the smaller organizations as much influence as the larger ones. ${ }^{54}$ The party suggested that the member organizations should be allocated votes in proportion to their size.

In 1919 the Social Democratic Left Party, the Left Party's youth organization, and the Young Socialists' Party, were all members of the ABF. ${ }^{55}$ In addition, the Railroad Workers' Union sympathized with the Left Party. Meanwhile, the separate syndicalist labor federation (SAC) had grown and was putting considerable energy into its education program. ${ }^{56}$ It was only a matter of time before the SAC, too, would apply for membership in the ABF. Under the existing rules, the left-wing organizations would then have a firm majority of votes in the ABF's governing body. ${ }^{57}$ Even without the SAC in the mix, the SAP at first failed to win over a majority to support its proposal to change the voting rules and the issue was postponed. ${ }^{58}$

At the next meeting three months later, the SAP presented a report on the ABF's finances, which concluded that its membership fees were too low to cover its expenses. Either the ABF would have to make cutbacks or the membership fee had to be increased. All the members of the governing body agreed that the fee had to be raised, but several hesitated to give their firm approval, including the LO, arguing that the change needed to be ratified by their organization. The LO also pointed out that if the organization was to pay more, it would need more influence over how the money was spent. It would not finance the education organized by rival organizations. ${ }^{59}$ 
Connecting the proposal on changed voting rules with raised fees made it harder to turn down the SAP's proposal, and the smaller organizations realized that the LO and the SAP could leave the ABF unless the voting rules were changed. Their departure would have been financially devastating for the ABF. It would also have been devastating for the left-wing organization, which throughout the period struggled with insufficient funding. The small leftwing organizations, including the Left Party and its youth organization, were opposed to a change, but in the end they had no choice but to accept it. They could never fund on their own the infrastructure (libraries, etc.) for workers' education that the ABF possessed. ${ }^{60}$ The majority therefore adopted both the dues increase and the SAP's original proposal that voting within the governing body should be proportionate to the number of members. ${ }^{61}$

The new provisions changed the composition of the ABF's governing body and thus power relations within the ABF. The timing of the changes prevented the left-wing organizations from gaining any notable influence over the $\mathrm{ABF}^{62}$ After the reformists seized power in 1919, workers' education was uncontroversial in Sweden. There was only one organization arranging workers' education, and it was controlled by the SAP and the LO. Moreover, workers' education in Sweden was certainly independent from established educational institutions, and no cooperation with universities existed. But workers' education was not independent from the labor movement organizations, as was the case in Britain. The ABF was not an independent actor, but a mere instrument for the unions and political parties that were members. Neither could the ABF advocate radical ideas: The reformist organizations' majority in the ABF was able to block all such attempts.

The efforts to seize control over the ABF also testify to how important workers' education was to the LO and the SAP, which had launched a concerted campaign to win its members, and the workforce more generally, over to its reformist approach to social reform. ${ }^{63}$ The advantages of controlling the ABF for such an endeavor were clear, as it had already established libraries across the country, which could serve as a vehicle for the LO's and the SAP's educational activities.

In Sweden, as in Britain, a variety of teaching methods were used in the labor movement's educational programs, including lectures, evening courses, and correspondence courses. Lectures were very often given by labor leaders. In the 1920s the leadership of the LO (the Landssekretariatet) regularly traveled the country to give lectures - and not only political speeches. Other lecturers were recruited from the people's high schools. ${ }^{64}$ These study forms were not, however, considered as important as the study circle. The study circle was an important legacy from the temperance movement. The temperance movement activist Oscar Olsson's ideal circles did not have teachers, and the role of chairman at meetings rotated among the participants. According to Olsson, the chair's role was a learning experience in itself and was supposed to maintain the nonhierarchical and democratic characteristics of the circles. ${ }^{65}$ Popular education was to be a process of learning and teaching. ${ }^{66}$ 
Besides being democratic and nonhierarchical, the study circle was free and voluntary. No one could force study circle participants to study a particular subject. Though they were encouraged to study certain subjects, participants were free to choose subjects on their own. Study circles were also voluntary in the sense that participation was based solely on the participant's urge to learn. ${ }^{67}$ The study circles can thus, in effect, be described as informal education. $^{68}$

The average number of participants in the study circles during the 1920s was thirteen. ${ }^{69}$ The study group chose a topic and acquired a syllabus, usually from the local ABF library. The regulation of the library grants offered study circles economic support to cover the cost of books, on condition that the books would be handed over to a library after use. ${ }^{70}$ In the 1920 s the norm among unionists at the work place level was to have study circles. The circle could be kept alive for years and would change subjects every semester and maybe participants. They were considered to be an integral institution of the local union activities in the 1920 s and 1930s. ${ }^{71}$

\section{Conclusions}

How did workers' education in Britain and Sweden differ, and what are the implications of the differences? As shown in the figure below, a comparison of the education systems in Sweden and Britain revealed two very different systems. In Sweden, workers' education was centralized in one organization, the ABF, which was controlled by the reformist labor movement. There was no room for the ABF to act independently. Moreover, the labor leadership had realized the potential of workers' education early on, and by the 1930s an average of 37,500 workers a year attended study circles designed by the LO and SAP. ${ }^{72}$ In Britain, on the other hand, the educational institutions were multiple: the WEA, WETUC, NCLC, and LRD were all different bodies with different agendas. Above all, the different organizations that provided and organized workers' education in Britain were fairly independent from the unions and the Labour Party, and they operated as independent actors. Ideologically driven activists - socialists or actors advocating liberal values - could operate within these institutions.

The British and the Swedish cases also differ regarding the teaching methods used, and this likely had an impact on the potential for workers' education to form a cohesive class identity. The British labor leaders acknowledged the importance of workers' education, but from their point of view workers' education aimed to primarily educate activists and workers (thus workers' education in Britain stressed what research on adult education calls nonformal education ). ${ }^{73}$ Stressing education does not necessarily promote political schooling. The composition of the populations of Sweden and Britain at that time was very different, having a greater number of pockets of population density. ${ }^{74}$ This should have encouraged study groups, so it is curious that the study circle method gained limited influence in Britain. In Sweden, however, enlightenment 
and ideological schooling of the working class was the core of workers' education, and the main study method was the study circle. The signature of the Swedish workers' education movement was "free and voluntary," but considering how workers' education was designed, labor leaders had better preconditions to control the content of the courses and thus use it as a means for identity formation.

Table One. Summary of the Conclusions

\begin{tabular}{|c|c|c|}
\hline $\begin{array}{l}\text { Workers' } \\
\text { education }\end{array}$ & Britain & Sweden \\
\hline \multirow{2}{*}{$\begin{array}{l}\text { Structure of the } \\
\text { system }\end{array}$} & Split: Several organizations & Unified: One organization \\
\hline & $\begin{array}{l}\text { Independent of the trade unions and } \\
\text { political parties }\end{array}$ & $\begin{array}{l}\text { Controlled by labor movement } \\
\text { organizations }\end{array}$ \\
\hline \multirow{2}{*}{$\begin{array}{l}\text { Forms of } \\
\text { education }\end{array}$} & Teacher-centered classes & Student-centered study circles \\
\hline & Teacher-led/Hierarchical & Self-learning/Democratic \\
\hline
\end{tabular}

This article took its point of departure from the larger theoretical question about the role of ideological schooling for class formation processes. What implications do the results have for the class formation literature? The part played by workers' education in identity formation processes and the creation of a cohesive working class cannot be determined solely by this limited study, and more research is needed to make such claims. However, this analysis strengthens the hypothesis that the ideological schooling of the grass roots does have an impact on class formation.

Whereas workers' education does not appear to have been an instrument for ideological schooling in Britain, the design and control of the workers' education system in Sweden suggests a strategic use of workers' education, something that surely played an important role in the formation of a very cohesive and strong labor movement. The reason for this was the perceived threat from the newly formed, radical left-wing groups. The LO clearly saw the new left-wing organizations that joined the $\mathrm{ABF}$ as a threat not only to unity in $\mathrm{ABF}$, but unity within the entire labor movement. ${ }^{75}$ The TUC might have perceived the left-wing groups in Britain the same way, but strategies to handle this problem differed from the LO's. It has been claimed that the British labor movement lacked "ideological commitment," ", which also might have impacted the way workers' education was designed. The lack of a clear ideology in the British labor movement had the advantage that ideological plurality existed 
without tearing the labor movement apart (which was the case in Germany). However, without a clear ideology, there is always a risk that the core of the movement was perceived as ill-defined by members and potential members.

Research has shown that identity formation processes in organizations are usually triggered by internal or external threats that force the leadership to question current self-perceptions. ${ }^{77}$ For the Swedish labor movement the leftwing groups became such a threat to unity, and workers' education became the means to create cohesiveness. Similar processes did not take place in Britain. In both cases, workers' education fulfilled a function in the class formation processes: It reproduced diversity in Britain, whereas it became the means for a strategy to construct a particular collective identity in the Swedish labor movement. Of course, workers' education is not the only explanation for differences between national labor movements, but it is a variable that, until now, has been neglected in class formation literature and is indeed a variable that provides us with more insights into how class formation processes work, demonstrating great potential for further research.

\section{NOTES}

1. The author would like to thank the following people for insightful comments and constructive feedback on this text: the three anonymous ILWCH reviewers, Stefan Berger, Maya John, Mary-Jane Fox, Michael Merrill, the participants at the 2015 Mimer Conference in Stockholm, and the participants at the 2016 AILH conference in New Delhi.

2. Helga Grebing, "Auseinandersetzung mit dem Nationalsozialismus," in Sozialdemokratische Arbeiterbewegung und Weimarer Republik, ed. Wolfgang Luthardt (Frankfurt 1978); Michael Ruck, Bollwerk gegen Hitler? Arbeiterschaft, Arbeiterbewegung und die Anfänge des Nationalsozialismus (Köln, 1988).

3. See for example Étienne Balibar, "On Reproduction," in Reading Capital, ed. Louis Althusser and Étienne Balibar (London, 1979) 267; Andrew August, "Narrative, Experience and Class: Nineteenth-Century Social History in Light of the Linguistic Turn," History Compass 9 (2011) 384-396; Jürgen Kocka, "Problems of Working-Class Formation in Germany: The Early Years, 1800-1875," in Working Class Formation, ed. Ira Katznelson and Aristide R. Zolberg (Princton, 1986) 279-330.

4. E.P. Thompson, The Making of the English Working Class (New York, 1966); Ira Katznelson, "Working-Class Formation: Constructing Cases and Comparisons," in WorkingClass Formation; Margaret R. Somers, "Narrativity, Narrative Identity, and Social Action: Rethinking English Working-Class Formation," Social Science History 16 (1992) 591-630; J.F. C. Harrison, Learning and Living 1790-1960: A Study of the History of the English Adult Education Movement (London, 1961).

5. Gareth Stedman Jones, Languages of Class: Studies in English Working Class History, 1832-1982 (Cambridge, 1984); M.W. Steinberg, Fighting Words: Working-Class Formation, Collective Action, and Discourse in Early Nineteenth-Century England (Ithaca and London, 1999).

6. Leonie Huddy, "From Social to Political Identity: A Critical Examination of Social Identity Theory," Political Psychology 22 (2001 127-156).

7. Jenny Jansson, Manufacturing Consensus: The Making of the Swedish Reformist Working Class (Uppsala, 2012).

8. Lars Arvidson, Folkbildning $i$ rörelse : pedagogisk syn i folkbildning inom svensk arbetarrörelse och frikyrkorörelse under 1900-talet - en jämförelse (Malmö, 1985), 142; Tom Steele, Knowledge is Power! The Rise and Fall of European Popular Educational Movements, 1848-1939 (Bern, 2007). 
9. Bernt Gustavsson, Bildningens väg: tre bildningsideal i svensk arbetarrörelse 1880-1930 (Stockholm, 1991), 29-30.

10. E. Andersson, A.M. Laginder, S. Larsson and G. Sundgren, "Cirkelsamhället," SOU:47 (Stockholm, 1996); Pelle Åberg, Translating Popular Education: Civil Society Cooperation between Sweden and Estonia (Stockholm, 2008), 62-74; H. Nordvall and L. Malmström, "Den folkligt bildade politikern - Akademiska kunskaper och det symboliska kapitalets logik inom den socialdemokratiska riksdagsgruppen i Sverige," Nordisk kulturpolitisk tidsskrift 2 (2015) 234-249.

11. Axel Hadenius, Facklig organisationsutveckling. En studie av Landsorganisationen $i$ Sverige (Stockholm, 1976), 25-30. 333.

12. Edward Shorter and Charles Tilly, Strikes in France, 1830-1968 (Cambridge, 1974),

13. OECD, “Trade Union Density," http://stats.oecd.org/ (accessed May 5, 2013).

14. Jenny Jansson, "Two Branches of the Same Tree? Party-Union Links in Sweden in the 21st Century," in Centre-Left Parties and Trade Unions in the Twenty-First Century, ed. Elin H. Allern and Tim Bale (Oxford, 2016).

15. Martin Crick, The History of the Social-Democratic Federation (Edinburgh, 1994); Nina Fishman, "The Phoney Cold War in British Trade Unions," Contemporary British History 15 (2001); Mary Hilson, Political Change and the Rise of Labour in Comparative Perspective: Britain and Sweden 1890-1920 (Lund, 2006), 14-18.

16. Stefan Berger, The British Labour Party and the German Social Democrats, 1900-1931 (Oxford, 1994), 6-10.

17. Hilson, Political Change.

18. ILO, "Strikes and Lockouts UK," http://laborsta.ilo.org/STP/guest\#list (accessed May 8, 2013); Shorter and Tilly, 333; Baston, “The Age of Wilson 1955-1979," in The Labour Party: A Centenary History, ed. B. Brivati and R. Heffernan (London, 2000), 87-111.

19. Alastair Reid, "A New Paradigm for British Labour History," History Compass 3 (2005) 1-26; Gösta Esping-Andersen, The Three Worlds of Welfare Capitalism (Princeton, NJ, 1990); K. Jeffreys, "The Attlee Years, 1935-1955," in The Labour Party, ed. B. Brivati and R. Heffernan, (London, 2000) 68-86; K. Laybourn, "Labour in and out of Government, 1923-1935," in The Labour Party, 50-67.

20. Russell Abratt, "A New Approach to the Corporate Image Management Process," Journal of Marketing Management 5 (1989) 63-76; W. Olins, The New Guide to Identity: How to Create and Sustain Change through Managing Identity (Aldershot, 1995); C.B.M. Van Riel and J.M.T. Balmer, "Corporate Identity: The Concept, its Measurement and Management," European Journal of Marketing 31 (1997) 340-355.

21. Ralph Darlington, Radical Unionism: The Rise and Fall of Revolutionary Syndicalism (Chicago, 2013).

22. For more information on the workers' education movement in Britain, see, for instance, J.F.C. Harrison, A History of the Working Men's College, 1854-1954 (London, 1954); J. Holford, Union Education in Britain: A TUC Activity (Nottingham, 1994).

23. Mary Danvers Stocks, The Workers' Educational Association: The First Fifty Years (London, 1953); John H. Nicholson, "Workers' Education in Great Britain," International Labour Review 29 (1934).

24. Stocks, The Workers' Educational Association, 80-81.

25. Valerie Quinney, "Workers' Education: A Confrontation at Ruskin College," American Journal of Education 92 (1983) 52-78; NCLC, Education for Emancipation: The Work of the National Council of Labour Colleges (NCLC Box 1/WCML Manchester, 1925).

26. Labor colleges were colleges organized and controlled by the labor movement to provide education for the working class. Several such colleges were founded in Great Britain at this time.

27. NCLC, Education for Emancipation.

28. A.J. Corfield, Epoch in Workers' Education-A History of the Workers' Educational Trade Union Committee (London, 1969), 17-18.

29. NCLC, Education for Emancipation, 5.

30. Arthur Woodburn, Labour's Educational Needs. Presidential Address to the Seventeenth Annual Conference of NCLC (NCLC Box 1/WCML Manchester, 1938); Arthur Woodburn, Education and the Struggle for Power. Presidential Address to the Sixteenth Annual Conference of NCLC (NCLC Box 1/WCML Manchester, 1937 
31. NCLC, Education for Emancipation, 6.

32. Corfield, Epoch in Workers' Education, 19; G.D.H. Cole, The British Labour Movement. A Syllabus for Classes and Study Circles (LRD Box 1/WCML Manchester, 1920), 25.

33. Ernest Green, Look Both Ways... (WEA Box 1/WCML Manchester, n.d.), 3.

34. Stocks, The Workers' Educational, 83; WEA, Workers' Education in Great Britain (WEA Box 2/WCML Manchester, 1943); P. Jarvis and C. Griffin, Adult and Continuing Education: Major Themes in Education (London, 2003), 67.

35. Nicholson, "Workers' Education in Great Britain," 663; Corfield, Epoch in Workers' Education, 5.

36. Patricia Pugh, Educate, Agitate, Organize: 100 Years of Fabian Socialism (London, 2010), 117 ff; G.D.H. Cole, Fabian Socialism (London, 1943), 171-71.

37. T. Gårdlund, Promemoria no III. Fristående ekonomiska utredningsinstitutioner $i$ den engelska fackföreningsrörelsens tjänst: Labour Research Department (LO 2964/E/14/5, ARAB, Stockholm,1938); Pugh, Educate, Agitate, Organize, 124, 132; LRD (Box 1).

38. Tom Steele, "Enlightened Publics: Popular Education Movements in Europe, their Legacy and Promise," Studies in the Education of Adults 42 (2010) 107-123; John Fletcher Clews Harrison, A History of the Working Men's College, 1854-1954 (London, 1954).

39. Lawrence Goldman, "Education as Politics: University Adult Education in England Since 1870," Oxford Review of Education 25 (1999): 92.

40. Albert Mansbridge, University Tutorial classes: A Study in the Development of Higher Education among Working Men and Women (London, 1913).

41. WEA, W.E.A. Foundation and Purpose (WEA Box 1/WCML Manchester, 1947), 11

42. G.D.H. Cole, Hints on Reading and Writing (WEA Box 1/WCML Manchester, 1950), $2-3$.

43. Mansbridge, University Tutorial Classes; R. Turner, "Workers' Educational Association Tutorial Classes and Citizenship in Scotland, 1907-1939," History of Education 38 (2009): 367-81.

44. Lawrence Goldman, "Intellectuals and the English Working Class 1870-1945: The Case of Adult Education," History of Education 29 (2000): 281-300.

45. NCLC, Education for Emancipation.

46. Goldman, "Education as Politics," 92.

47. For more information on the popular education movement in Sweden, see B. Gustavsson, Bildningens väg : tre bildningsideal $i$ svensk arbetarrörelse 1880-1930 (Stockholm, 1991); B. Andersson, Folkbildning i perspektiv: studieförbunden 1870-2000, organisering, etablering och profilering (Stockholm, 1980); R. Ambjörnsson, Den Skötsamme Arbetaren (Stockholm, 1998).

48. Ambjörnsson, Den Skötsamme Arbetaren.

49. Jim Crowther, "Reflections on Popular Education in the UK and Sweden," in Popular Education, Power and Democracy: Swedish Experiences and Contributions, ed. Ann-Marie Laginder, Henrik Nordvall, and Jim Crowther (Leicester, 2013), 261-62.

50. Hugo Heffler, Arbetarnas bildningsförbund 1912-1962: krönika vid halvsekelgränsen (Stockholm, 1962).

51. Jansson, Manufacturing Consensus; Jenny Jansson, "Maktkamp i ABF," Arbetarhistoria (Stockholm, 2015), 153-54.

52. ABF Representantskap, Protokoll fört vid sammanträde med ABFs representantskap den 10 maj (ABF A/01/A/01, ARAB, Stockholm, 1918b).

53. ABF Representantskap, Protokoll fört vid ABFs representantskapsmöte den 8 augusti (ABF A/01/A/01, ARAB, Stockholm, 1918a), see bilaga 3.

54. ABF Representantskap, Protokoll fört vid ABFs representantskaps årsmöte den 13 juli (ABF A/01/A/01, ARAB, Stockholm, 1919b).

55. ABF Representantskap, Protokoll fört vid extra sammanträde med ABFs representantskap den 23 maj (ABF A/01/A/01, ARAB, Stockholm, 1919c).

56. See SAC's annual reports 1910-1925.

57. Representantskap, Protokoll fört vid ABFs representantskaps årsmöte den 13 juli (ABF A/01/A/01, ARAB, Stockholm,1919c). The SAP eventually did join the ABF in 1923.

58. Ibid.

59. ABF Representantskap, Protokoll fört vid ABFs representantskaps ajournerade årsmöte $i$ Stockholm den 9 oktober (ABF A/01/A/01, ARAB, Stockholm, 1919a).

60. Ibid. 
61. ABF, Protokoll fört vid ABF:s representantskaps möte den 23 september (ABF A/01/A/ 01, ARAB, Stockholm, 1920a).

62. Representantskap, Protokoll fört vid ABFs representantskaps ajournerade årsmöte $i$ Stockholm den 9 oktober; Representantskap, Protokoll fört vid ABFs representantskaps årsmöte den 13 juli; ABF, Verksamhetsberättelse arbetsåret 1919-1920 (Stockholm, 1920b).

63. Jansson, Manufacturing Consensus, 96-125.

64. Jansson, Manufacturing Consensus, 114-118.

65. Ingvar Törnqvist, Oscar Olsson folkbildaren: $i$ synnerhet hans tankar om universitetens roll $i$ folkbildningsarbetet (Stockholm, 1996), 26-30.

66. Bo Andersson, Folkbildning i perspektiv: studieförbunden 1870-2000, organisering, etablering och profilering (Stockholm, 1980), 19.

67. Bernt Gustavsson and Matilda Wiklund, Nyttan med folklig bildning: en studie av kapitalformer $i$ folkbildande verk (Lund, 2013), 7-11.

68. Haim Eshach, "Bridging In-school and Out-of-school Learning: Formal, Non-Formal, and Informal Education,” Journal of Science Education and Technology 16 (2007) 171-190.

69. ABF Verksamhetsberättelser, 1920-1929.

70. Heffler, Arbetarnas bildningsförbund, 25-26; Arvidson, Folkbildning i rörelse, 50; Andersson, Folkbildning i perspektiv, 107-108.

71. Jansson, Manufacturing Consensus.

72. Jansson, Manufacturing Consensus, 215.

73. Michael Eraut, "Non-Formal Learning and Tacit Knowledge in Professional Work," British Journal of Educational Psychology 70 (2000) 113-136; Haim Eshach, "Bridging In-School and Out-of-School Learning."

74. Hilson, Political Change, 34-41; Bladh, Ekonomisk historia: Europa och Amerika 1500-1990 (Lund, 1995), 120-38.

75. Jansson, "Maktkamp i ABF."

76. Hilson, Political Change, 47-48.

77. Abratt, A New Approach; Olins, The New Guide to Identity; Van Riel and Balmer, "Corporate Identity." 